\title{
Ortaöğretim Öğrencilerinin Dijital Oyun Oynama Motivasyonları ve Oyun Oynama Davranıșlarının Farklı Zamanlarda İncelenmesi
}

\author{
Examination of Secondary School Students' Digital Gaming Motivations and \\ Gaming Behaviors at Different Times
}

\author{
(1) Beyza YILMAZ1 \\ ${ }^{1}$ Bașkent Üniversitesi Sağlık Bilimleri Fakültesi, Sosyal Hizmet Bölümü, Ankara, Türkiye
}

\section{Öz}

Amaç: Bu çalışma ortaöğretim öğrencilerinin akademik yıl ve yaz tatili içerisindeki oyun oynama davranışlarını karşılaştırmak amacıyla gerçekleștirilmiştir.

Yöntem: Araştırma nicel araştırma yöntemlerinden tarama modeli ile gerçekleștirilmiștir. Farklı zamanlardaki oyun oynama davranışlarının anlaşılması için tarama modellerinden ilișkisel desen kullanılmıştır. Araştırmanın ölçme aracı, kişisel bilgi soru formu, Dijital Oyun Oynama Motivasyonu Ölçeği ve Çevrimiçi Oyun Bağımlılık Ölçeği olmak üzere üç bölümden oluşmaktadır. Ankara ili Yenimahalle ilçesinde rastgele seçilen bir lisede 2018-2019 eğitim-öğretim yılı bahar dönemi ve yaz tatili sonunda 9, 10 ve 11. sınıflar arasından, tabakalı örneklem yöntemi kullanılarak ulaşılan 300 öğrencinin soru formuna verdiği yanıtlar analiz edilmiștir.

Bulgular: Eğitim-öğretim yılı içerisinde oyun oynayan öğrencilerin, yaz tatili içinde oynayan öğrencilere göre anlamlı bir biçimde çevrimiçi oyunlara daha bağımlı ve yüksek düzeyde oynama motivasyonuna sahip oldukları gözlenmiştir. Hem akademik yıl içinde hem de yaz tatilinde daha uzun süre, sık aralıklarla oyun oynayan öğrencilerin daha kısa süre, daha az aralıklarla oynayanların daha seyrek oynayanlara göre oynama motivasyonları yüksektir ve oyun bağımlığına yatkındırlar.

Sonuç: Çocuk ve gençlerin iyilik hallerinin artıııması noktasında çalışmalar yürüten sosyal hizmet disiplininin, sahip olduğu bütüncül bakış açısı ile dijital oyun oynama davranışlarına hem kuramsal hem de uygulamalı çalışmalarla ışık tutması beklenmektedir.

Anahtar kelimeler: Dijital oyunlar, problemli oynama davranıșı, ergenlik

\section{Abstract}

Objective: This study was carried out to compare the gaming behaviors of secondary school students during the academic year and summer vacation. Method: The research was carried out with the screening model, which is one of the quantitative research methods. Relational design, one of the scanning models, was used to understand the gaming behaviors at different times. The measurement tool of the research consists of three parts: Personal Information Questionnaire, Digital Game Motivation Scale and Online Game Addiction Scale. At a randomly selected high school in Yenimahalle district of Ankara province, the answers of 300 students from 9th, 10th and 11th grades, reached by using the stratified sampling method, at the end of the spring semester and summer vacation of the 2018-2019 academic year, to the questionnaire were analyzed.

Results: Students who play games during the academic year are significantly more dependent on online games and have a higher level of motivation to play than students who play during the summer vacation. Students who play games for longer and more frequently both during the academic year and during the summer vacation are more motivated and prone to game addicton to play than those who play for shorter periods, and those who play less frequently.

Conclusion: It is expected that the social work discipline, which works to increase the well-being of children and young people, will shed light on digital game playing behaviors with both theoretical and practical studies with its holistic perspective.

Keywords: Digital games, problematic gaming behavior, adolescent

Not: Bu çalıșmanın bir kısmı Uluslararası Ergenlik ve Gençlik Araştırmaları Kongresi’nde (29 Nisan - 01 Mayıs 2021) sunulmuș olup, tam metni yayınlanmamıștır.

Yazıșma Adresi/Address for Correspondence: Beyza YILMAZ, Bașkent Üniversitesi Sağlık Bilimleri Fakültesi, Sosyal Hizmet Bölümü, Ankara, Türkiye

E-posta: beyzayilmaz@baskent.edu.tr

ORCID ID: 0000-0002-6963-2036
Gelis Tarihi/Received: 07.06.2021

Kabul Tarihi/Accepted: 30.09 .2021 


\section{Giriş}

Geçmiş̦ten bugüne var olmuş her toplumda oyun ile ilgili ögelerle karşılaşılması oyunun, insan hayatında önemli bir rolü olduğunu göstermektedir (1). Öyle ki ilk zamanlarda basit bir taklit etme davranıșı olarak ortaya çıkan bu olgu, zaman içerisinde inanç, savaş, sanat gibi birçok önemli yaşam ritüelinin bir parçası haline gelmiştir (2). Yıllar boyunca oyunlar, hem çocukların hem yetișkinlerin boș zaman değerlendirme, sıkıntı ve stresten kaçma, başarma hissini tatma, merak gibi amaçlarına ve oynayanların çeşitli becerilerini geliștirmelerine katkıda bulunmuştur. Özellikle çocuklarda geliş̧me dönemlerini kolaylıkla şekillendiren oyunlar çocukların ince ve kaba motor becerilerini, bilișsel ve dil gelișimlerini, yaratıcılıklarını, sosyal ilişkilerini biçimlendirmektedir. Geçmiște hayvan kemikleri, ağaç kabukları, dallar, yapraklar, toprak ile oynanan oyunlar günümüzde yerini büyük bir piyasaya sahip olan teknolojik araçlara bırakmıştır. Son yıllarda teknolojinin gelișimiyle, çoğu kiși internete, artan çeșitlilikte elektronik cihazlarla erișmektedir ve dijitalleşmenin artmasıyla sanal dünyada yaşamaya başlanılmıştır. Bunların yanı sıra, kentleșme ile çocukların oynayabileceği alanlar daralmış, ebeveynlerin yoğun çalıșma şartlarının da etkisiyle (3) bu dünyada doğan, büyüyen çocukların oyunları da dijital ekranlardan ibaret olmuștur.

Dijital oyunların, mobil cihazların ve bilgisayarların ucuzlaması ve yaygınlaşması, her yaştan, her zevke sahip kullanıcılara hitap eden oyunların tasarlanması oyun oynama faaliyetlerine katııımı, oynama sürelerini ve sıklıklarını artırmıștır. Oyunlar özellikle çocuklar ve gençlerde bireylerin farklı psikososyal intiyaçlarını karșılamaya bașlamasıyla dijital dünyanın vazgeçilemez unsurlarından olmaya bașlamıștır. Oyunların çocuk ve gençlerin gelişimine el-göz koordinasyonu sağlama, sosyalleșme, odaklanma becerilerini geliștirme gibi katkıları olsa da; çocukların ve gençlerin biyolojik, sosyal, akademik, psikolojik yaşantılarında olumsuz sonuçlara yol açacak yönleri de bulunmaktadır. Bireylerin biyopsikososyal iyilik halinin artırılması amacıyla çalıșan sosyal hizmet disiplini için bireylerin iyilik hallerinin önünde engel olușturacak oyun oynama faaliyetlerinin incelenmesi önemlidir.

Bu araştırma ile günümüz çocuklarının gün içinde uzun sürelerce vakit harcadıkları oyun oynama davranışlarının akademik yıl içinde ve yaz tatili içerisinde farklılaşıp farklılașmadığı, eğer farklılașma var ise hangi süreçte oyun oynama davranışının fazla olduğu ortaya koyulmak istenmektedir.

Günümüzdegelenekseloyunlarteknolojikgelișmevedeğișmelerle yerini dijital ortamlara bırakmaktadır. Bu ortamlarda olușturulan yeni oyun kültürü "dijital oyun" olarak adlandırılmaktadır. Dijital oyun tıpkı geleneksel oyunlar gibi kendi kurallarına sahip, belirli bir zaman ve mekanda gerçekleșen, oynayıının farklı amaçlarla dahil olduğu etkinliklerdir. Literatürde video oyunu, bilgisayar oyunu olarak da tanımlanan dijital oyunlar, bedensel faaliyetlere dayanan geleneksel oyunların aksine, klavye, fare, joystick gibi araçlarla oynanmaktadır (4). Dijital oyunlar; çevrimiçi (online) veya çevrimdışı (offline), tek kişi (single player) veya çoklu (multiplayer), ya da yapay zekâya karşı oynanabilmektedir. Dijital oyun kavramsallaștırması ile mobil oyunların, bilgisayar oyunlarının, konsol oyunlarının farklı ve tüm türleri tanımlanmaktadır (5).

Dijital oyunlardaki popülaritenin yanı sıra dijital oyunları oynayan kişilerin oyun oynarken çektikleri video kliplerin ya da canlı yayınların izlenmesi de son zamanlarda ortaya çıkan, oyuncu kitlesinin hatırı sayılır bir kısmına hitap eden yeni bir olgudur. Oyuncular oyunlarda daha başarılı olabilmek, yeni taktikler öğrenebilmek ya da boş vaktini değerlendirmek gibi farklı amaçlarla bu yayınları izlemekte ve kendi yayınlarını çekerek paylaşmaktadırlar. Bu yayınlar Twitch, Youtube gibi farklı kanallar üzerinden izlenebilmektedir. 2019 yılında Twitch üzerinden video izleyen kullanıcıların ekran karşısında geçirdikleri ortalama süre 3,9 saat iken, bu süre 2020 yılında 5,8 saate ulașmıștır (6).

Dijital oyunların gelișimi günden güne artmaktadır. Oyunlar, daha gerçekçi sahneler, daha iyi görüntü ve ses kalitesi, farklı beğenilere hitap edecek oyun içi görev ve roller içerdikçe daha çok kabul görmekte ve insanları oyun oynamaya yöneltmektedir (7).

Lise öğrencileri bulundukları ergenlik dönemi itibariyle bir yetişkinden daha farklı intiyaç ve sorunlara sahiptir. "Ergenler, kim olduklarına, hayattan ne istediklerine, ne tür bir insan olmak istediklerine dair bir anlayış geliștirme mücadelesi vermekte ve gelecek kimliklerinin olası hallerini temsil eden rollerle deneme gerçekleștirmektedirler. Kimlik krizini çözme çabası ergeni, duygusal bağlanma, așırı adanma, yabancılaşma, isyan ya da başıboşluk yollarına sürükleyebilecek kadar parçalayabilmektedir" (8). Arkadaşları ile yakınlık kuramayan, ailesi ile olumlu ilișkileri bulunmayan, günlük hayatında sorunlar yaşayan, içe dönük kişilik özelliğine sahip olan, başarma duygusunu sosyal hayatındaki eylemlerinde hissedemeyen, fiziksel görünümünde saklamak istediği bir olumsuzluğun olduğunu düşünen ergenler, idealize ettikleri kimlik ve karakterler üzerinden oyuncu topluluğuna girmekte ve daha rahat sosyalleșmektedirler (9); (10); (11); (12). Ergenler oyunlarda ergenlik döneminin önemli krizlerinden biri olan toplumsal baskıları yaşamadan özgürce davranabilme imkanına sahip olmaktadırlar (13).

Dijital oyunların çocukların gelişimlerine etkileri genel olarak değerlendirilecek olursa özellikle bilişsel gelişimlerine katkı sağlaması doğrultusunda stratejik düşünebilme, hızlı ve doğru karar verme, problem çözme, teknoloji kullanımını ve oyunların çŏ̆unun İngilizce olmasından dolayı İngilizce bilgisini artırma 
gibi olumlu etkilerinin olduğu ileri sürülmektedir (14). Ancak bu oyunların, katkılarının yanında birçok olumsuz etkilerinin de olduğu görülmektedir. Oyunlar çocukları yalnızlaștırarak, gerçek dünyanın sosyal yaşamından koparmakta buna bağlı olarak çocuklar yeni sosyal ortamlara girmekte, iletişim kurmakta zorluk yaşamaktadır (11). Oyunların içeriği çocukları etkilediği görülmektedir. Şiddet içerikli oyunları oynayan çocuklar, şiddet duygusunu ve davranışını içselleștirip, normalleștirerek, șiddeti günlük yașamında bir iletişim biçimi olarak kullanan bireyler olmaya yatkın hale gelmektedir (15). Oyun içeriğinin yanı sıra oyunda geçirilen süre ve oyun oynama şekilleri de çocuklar üzerinde olumsuz etkiler içermektedir. Oyunu kazanabilmek için saatlerce bilgisayar başında oturan çocuklarda kas ve kemik sorunları, görme problemleri, dolaşım sistemi sorunları, uyku ve yemek yeme ihtiyaçlarını ertelemeye bağlı olarak farklı sorunlar ortaya çıkmaktadır (16); (17).

Hayatın ayrılmaz bir parçası haline gelen internet ve dijital oyunlar beraberinde bir takım sorunları da getirmiștir. Sürekli internete bağlı olan, oyun oynayan, cep telefonu ile vakit geçiren ve bu sebeple yașamlarında pek çok sorun oluşan bireylerin artması "internet bağımlılığı", "teknoloji bağımlılığı", "dijital oyun bağımlıı̆̆ı" kavramlarını ortaya çıkarmıştır (18). Dijital oyun bağımlılı̆̆ının itici faktörlerini değerlendirmek için çeşitli bakış açıları ve yaklaşımlar kullanılmıștır. Daha önceki oyun bağımlılığı çalışmaları, insanları oyun bağımlıı̆̆ı geliştirmeye yatkın kılan çeşitli faktörlere (oyun oynama motivasyonları, kişilik özellikleri, oyunun yapısal özellikleri, kültürel ve sosyal faktörler vb.) odaklanmıştır. Son zamanlarda ise bazı araştırmacılar saldırganlık, depresyon ve yalnızlık gibi psikososyal faktörlerin bireyleri oyunlara bağımlı hale getirebileceklerini öne sürmüşlerdir (19). Amerikan Psikiyatri Birliği (APA) tarafından geliștirilen ve Mayıs 2013'te yayımlanan Ruhsal Bozuklukların Tanısal ve İstatistiksel El Kitabı-5'in (DSM5) üçüncü araştırma ekinde dijital oyun bağımlılı̆ı, internette oyun oynama bozuklukları (internet gaming disorder) olarak ele alınmıştır (20). Oyun oynamak başlangıçta patolojik bir durumu ifade etmemektedir, oynama disfonksiyonel hale geldiğinde yani bireylerin akademik bașarılarında düşüșler, sosyal ve aile ilișkilerinde kopmalar, psikolojik ișleyișinde zararlar ortaya çıktığında oyun oynamanın patolojik olduğu söylenebilir (21). Ayrıca kimi araștırmacılar 'bağımlılık' yerine 'öz-yönetim eksikliği' ifadesinin, oyunlara gerçekten bağımlı olan kişilerin sayısının çok az olduğu tespitine dayanarak oyunların alışkanlığa bağlı kullanımını tanımlamak için uygun olabileceğini belirtmişlerdir (19).

Dijital oyunlar çocuk ve gençlerin yaşamına olumlu etkilerde bulunduğu gibi olumsuz etkilerde de bulunabilmektedir. Sosyal hizmet uygulamalı bir disiplin olarak davranışsal bağımlılıklardan biri olan dijital oyun bağımlılığı çalışmalarında sorunun değerlendirilmesi, bağımlılı̆ın/problemli kullanımın azaltılması ve nihai olarak ortadan kaldırılması için mikro düzeyden makro düzeye kadar psikososyal müdahaleler yürütür. Bireyle dijital oyunun problemli kullanımına/bağımlılığa yol açan faktörlerin keșfedilmesi için çalıșlır, benzer sorunlara sahip diğer oyuncularla birlikte grup çalışmaları düzenlenir. Dijital oyunların problemli kullanımı sebebiyle doğan sorunların keşfedilmesi ve çözülmesi için birey ve aile ile çalışılır. Bir halk sağlı̆̆ı sorunu olarak karșımıza çıkmaya bașlayan, özelde dijital oyun genelde ise teknolojik bağımlılıklar üzerine toplumla koruyucu önleyici ve rehabilite edici çalıșmalar yürütülür. Sosyal hizmet uzmanı bu çalışmalar sırasında danışmanlık rolü ile dijital oyun bağımlılı̆̆ı/problemli kullanımı olan bireye ve ailesine yönelik danışmanlık verir; eğitici rolü ile dijital oyun bağımlılığına yol açan faktörler, bağımlıı̆ıın etkileri hakkında eğitim verir, kaynak bulucu rolü ile problemli kullanımı/ bağımlılığı olan birey ve ailelerinin intiyaçlarının karşılanması için kaynaklarla bulușturulmasını sağlar, dijital oyun bağımlıı̆̆ı ile mücadele eden kuruluşlar arasındaki işbirliğini kolaylaştırır.

Gençlerin serbest zaman değerlendirme aracı olarak, sorunlardan kaçmak/uzaklașmak amacıyla dijital oyunları kullandıkları bilinmektedir(22, 23, 24). Bu bilgiler ışığında gençlerin akademik yıl içerisinde eğitim faaliyetlerinin stresi ve yorgunluğundan uzaklașmak amacıyla, yaz tatilinde ise serbest zamanı değerlendirme aracı olarak oyunları kullanabileceği düşünüldüğünde, dijital oyunlar öğrencilerin ihtiyaçlarını karşıladığı bir araç olarak karşımıza çıkmaktadır. Dijital oyunların gençlerin yaşamında önemli intiyaçlarını karșılaması, gençlerin sorunlardan uzaklașmak, serbest zamanlarında vakit geçirmek istedikleri anlarda dijital oyunlara yönelmesi problemli oyun oynama davranıșına yol açabilmektedir. Bu bakımdan gençlerin biyolojik, psikolojik, sosyal ve akademik yaşantısı üzerinde etkilere sahip oyun oynama davranışı hem akademik hem de yaz tatili içerisinde incelenmek istenmiștir.

\section{Yöntem}

Bu çalışma ortaöğretim öğrencilerinin akademik yıl ve yaz tatili içerisindeki oyun oynama davranışlarını karșılaștırmak amacıyla nicel araştırma yöntemlerinden tarama modeli ile yapılmıştır. Farklı zamanlardaki oyun oynama davranışlarının anlaşııması için tarama modelinden ilișkisel desen kullanılmıștır. Iliş̦isel desen iki ya da daha fazla değişken arasındaki ilişkilerin ortaya çıkarılması amacıyla gerçekleștirilmektedir. Değişkenler arası birlikte değişimlerin ve/ya belirli bir değişken açısından karşılaştıııldığında anlamlı farklılașmaların olup olmadığı incelenir (25).

\section{Örneklem}

Araştırma Ankara ili Yenimahalle ilçesinde rastgele seçilen bir lisede 2018-2019 eğitim-öğretim yılı bahar dönemi ve güz dönemi başında yapılmış; örneklemi belirlemek tabakalı 
örneklem yöntemi kullanılmıștır. Soru formunun uygulandığı ilk dönem 12. sınıfa gitmekte olan öğrenciler, soru formunun ikinci kez uygulanacağı 2019-2020 akademik yılı güz dönemi bașında mezun durumda olacakları için örneklem hesaplamasına katılmamıştır. 2018-2019 bahar yarıyılında lisede 9. (265 kişi), 10. (203 kişi) ve 11. (180 kişi) sınıflarda toplam 648 öğrenci eğitim görmektedir. Toplam sayı içerisinde 9. sınıf öğrencilerinin dağılımı \%41, 10. sınıf öğrencilerinin dağılımı \%31 ve 11. sınıf öğrencilerinin dağılımı \%28'dir. Örneklem \%95 güvenilirlik düzeyinde 384 olarak belirlenmiștir. 384 örneklem sayısı, örneklem büyüklüğüne bakılmaksızın bulguların genellenebilirliği için asgari olarak yeterli görülmektedir (25). Örneklem sayısı sınıfların yüzdelerine göre bölünmüş ve 9 . Sinıflardan 158, 10. Sinıflardan 119 ve 11. sinıflardan 107 öğrenciye ulaşılması hedeflenmiștir. Soru formu 2018-2019 eğitim-öğretim yılı bahar döneminde basit tesadüfi örnekleme tekniği ile uygulanmış. Sınıfların listesinden rastgele belirlenen ve araștırmaya katılmaya gönüllü -soru formlarında kayıplar oluşabileceği tahmin edilerek 384'ten fazla kişiye ulaşılması hedeflenmiștir- 420 öğrenci soru formunu doldurmuștur. 20192020 eğitim-öğretim yılı güz dönemi bașında -yaz tatili sonu, eylül ayında- ise belirlenen örneklemden(384) yalnızca 300 kișiye ulașılabilmiștir. Yașanan bu veri kaybı öğrencilerin okul değiştirmesinden ve soru formlarının uygulandığı günlerde okula gelmemiş olmaları nedeniyle araștırmaya katılamamalarından kaynaklanmıștır. Araștırma, aynı örneklem grubunun dijital oyun bağımlııılarının akademik yıl içerisindeki ve yaz tatili sonundaki puanların karşılaştırılmasını hedeflediği için ikinci kez uygulanan soru formunu cevaplamamış olan öğrencilerin ilk soru formuna verdikleri yanıtlar değerlendirilmeye alınmamıștır.

\section{İşlem}

Veriler, önce 2018-2019 eğitim öğretim yılı mayıs ayında, sonra 2019-2020 eğitim öğretim yılı eylül ayı ilk haftasında soru formlarının araștırmaya katılmak isteyen öğrencilere dağıtılmasıyla toplanmıştır. Soru formunun basılı kopyaları araștırmacı tarafından yüz yüze dağıtılmıștır. Veri toplama sürecinde katılımcılardan aydınlatılmış onam alınmıștır. Araștırma gerçekleștirilmeden önce Bașkent Üniversitesi Sosyal ve Beșeri Bilimler ve Sanat Araștırma Kurulu'ndan 25.04.2019 tarih ve 17162298.600-242 sayı ile izin alınmıștır. Ayrıca 13.05.2019 tarih ve 14588481-605.99-E.9427693 sayı ile Milli Eğitim Bakanlığı'ndan da izin alınmıștır.

\section{Veri Toplama Araçları}

Araștırmanın ölçme aracı kişisel bilgi soru formu, Dijital Oyun Oynama Motivasyonu Ölçeği ve Çevrimiçi Oyun Bağımlılık Ölçeği olmak üzere üç bölümden oluşmaktadır. Soru formu hem akademik yıl içerisinde hem de yaz tatili sonunda uygulanmıștır.

\section{Kişisel Bilgi Soru Formu}

Araştırmacı tarafından oluşturulan kişisel bilgi soru formu, öğrencilerin sosyo-demografik bilgilerine, aile, okul ve arkadaşık ilișkilerine, oyun oynama süresi ve sıklı̆ına, oyunlarla ilgili videoları izleme durumlarına ilișkin 20 sorudan oluşmaktadır.

\section{Dijital Oyun Oynama Motivasyonu Ölçeği (D00MÖ)}

Ergenlerin oyun oynama motivasyonlarını ölçmek için Tekkurşun Demir \& Hazar, (26) tarafından geliștirilmiștir. Ölçek 'başarı ve canlanma', 'merak ve sosyal kabul' ve oyun isteğinde belirsizlik' olmak üzere 3 alt boyuttan ve 19 sorudan olușmaktadır. Ölçeğin Cronbach Alfa iç tutarlııı katsayısı 0,82, başarı ve canlanma alt boyutunun Cronbach Alfa iç tutarlııı katsayısı 0,70, merak ve sosyal kabul alt boyutunun Cronbach Alfa iç tutarlılık katsayısı 0,87 , oyun isteğinde belirsizlik alt boyutunun Cronbach Alfa iç tutarlıık katsayısı 0,72'dir.

\section{Çevrimiçi Oyun Bağımlıı̆̆ı Ölçeği (ÇOBÖ)}

Ayrıca ergenlerin bağımlılık düzeylerini ölçmek için Kaya (4) tarafından geliștirilmiştir. Ölçek 'aksaklıklar', 'başarı' ve 'ekonomik kazanç' olmak üzere 3 alt boyuttan ve 21 sorudan oluşmaktadır. Ölçeğin Cronbach Alfa iç tutarlılık katsayısı 0.91, aksaklıklar alt boyutunun Cronbach Alfa iç tutarlılık katsayısı 0.90, Başarı Alt Boyutunun Cronbach Alfa iç tutarlılık katsayısı 0.88, Ekonomik Kazanç Cronbach Alfa iç tutarlılık katsayısı 0.83 tür.

Bu araştırmada ise; akademik yıl içerisinde cevaplanan anketlerde ÇОВÖ Cronbach Alfa değeri 0,898; DOOMÖ Cronbach Alfa değeri 0,892 olarak bulunmuş. Yaz tatilinde ise çOBÖ Cronbach Alfa değeri 0,918, D00MÖ Cronbach Alfa değeri 0,907 olarak bulunmuștur. Buna göre kullanılan ölçeklerin güvenilirliklerinin oldukça yüksek olduğu söylenebilir.

\section{Veri Analizi}

Ulaşılan 300 öğrenci arasından yalnızca oyun oynayan öğrencilerin verdikleri yanıtlarda ölçeklerle gerçekleștirilen ilișkisel analizlere yer verilmiștir. Veriler IBM SPSS 17.0 yazııımı kullanılarak analiz edilmiștir. Ölçekten alınan puanların eğitimöğretim yılı içerisinde ve yaz tatili sonunda nasıl değiștiğini incelemek için eșleștirilmiş örneklem $t$ testi kullanılmıştır. Eğitim-öğretim yılı ve yaz tatili içerisinde bağımlı ve bağımsız değişkenler arasındaki farklılıklar Independent Samples T Testi ve One-Way ANOVA ile analiz edilmiștir. DOOMÖ ve ÇOBÖ arasındaki yordamayı incelemek için Basit Doğrusal Regresyon analizi yapıımıștır. 


\section{Bulgular}

Araștırmaya katılan öğrencilerin çoğunluğu $(\% 56,7)$ kızlardan olușmaktadır. Öğrenciler ağırlıklı olarak 15-16 yașlarındadır. Büyük çoğunluğunun ebeveynleri birliktedir ve öğrencilerin çoğunluğu aile içi ilișkilerinin iyi düzeyde olduğunu belirtmiștir. Katılımcı öğrencilerin neredeyse yarısı $(\% 48,7)$ 2018-2019 eğitimöğretim yılında 9. sınıfta olan öğrencilerden oluşmaktadır. Ayrıca öğrencilerin çoğunluğu arkadaşları ve okul personeli ile ilișkilerinin iyi düzeyde olduğunu; ders başarılarının ise orta seviyede olduğunu ifade etmiștir. Oyun oynayan ve oyunlarla ilișkili videoları izleyen öğrenciler arasında erkek öğrenciler kız öğrencilere göre bu faaliyetlere daha çok katılım göstermektedir. Katılımcıların sosyo-demografik bilgilerine ilişkin veriler Tablo 1 ve Tablo 3'te verilmiștir.

Öğrencilerin eğitim-öğretim yılı ve yaz tatili içerisindeki oyun oynama durumları incelendiğinde öğrencilerin daha çok eğitimöğretim yılı içerisinde oyun oynadıkları görülmüștür. Öğrencilerin eğitim-öğretim yılı ve yaz tatili içerisinde ÇOBÖ ve DOOMÖ'den aldıkları puanlar Tablo 2'de yer almaktadır.

Eğitim-öğretim yılı içerisinde oyun oynayan öğrencilerin, yaz tatili içinde oynayan öğrencilere göre anlamlı bir biçimde çevrimiçi oyunlara daha bağımlı ve yüksek düzeyde oynama motivasyonuna sahip oldukları gözlenmiștir $(p<0,05)$.
Öğrenciler akademik yıl içerisinde yaz tatiline göre oynadıkları oyunlar sebebiyle daha çok uyku düzeninde bozulma, yemek yeme, uyuma gibi temel ihtiyaçlarını erteleme, dersleri, işleri kaçırma, arkadașlık ilişkilerinde sorun yaşama gibi durumlarla karşılaşmakta ve oyun oynarken başarı hissini daha çok deneyimlemektedir. Ayrıca oyunlar sayesinde eğlenmekte, can sıkıntısından kurtulmakta, başarısızlıkları unutmakta, arkadașlarıyla takım kurma fırsatı elde etmekte, kazandıkça daha çok oynama isteğine sahip olmaktadırlar.

Yaz tatilinde ise eğitim-öğretim yılı içerisine göre oyun oynama faaliyetlerindeki ekonomik kazançları daha yüksektir. Öğrenciler oyunlar aracılığıyla oyun içi ya da gerçek yaşamda karşılık bulan paralar kazanmaktadırlar. Ancak yine de bu alt boyuttaki sorular incelendiğinde oyunlardan gelir elde eden öğrencilerin büyük çoğunluğu oluşturmadığı görülmüștür.

Öğrencilerin eğitim-öğretim yılı ve yaz tatili içerisinde ÇOBÖ ve D00MÖ'den aldıkları puanlar ile sosyo-demografik özellikleri ve oyun oynama faaliyetleri arasındaki ilişkiler aşağıdaki Tablo 3’te yer almaktadır.

Hem akademik yıl içinde hem de yaz tatilinde erkek öğrenciler kız öğrencilere göre daha yüksek düzeyde motivasyona ve bağımlılık düzeyine sahiptir.

Tablo 1. Katılımcıların sosyodemografik özellikleri

\begin{tabular}{|c|c|c|c|}
\hline & Çalıșma grubu & $\mathbf{n}$ & $\%$ \\
\hline \multirow{2}{*}{ Cinsiyet } & $\mathrm{KIZ}$ & 170 & 56,7 \\
\hline & Erkek & 130 & 43,3 \\
\hline \multirow[b]{2}{*}{ Yaş } & 16 & 114 & 38,0 \\
\hline & 17 & 75 & 25,0 \\
\hline \multirow{3}{*}{ Ebeveynlerin birliktelik durumu } & Evli & 272 & 90,7 \\
\hline & Ayrı & 23 & 8,0 \\
\hline & Ebeveyn vefat etmiş & 5 & 1,6 \\
\hline Sinıf & $\begin{array}{l}\text { 9. sınıftan 10'a geçen } \\
\text { 10. sınıftan 11'e geçen } \\
\text { 11. sınıftan 12'ye geçen }\end{array}$ & $\begin{array}{l}146 \\
88 \\
66\end{array}$ & $\begin{array}{l}48,7 \\
29,3 \\
22,0\end{array}$ \\
\hline \multirow[t]{2}{*}{ Kardeş sayısı } & 2 & 86 & 28,7 \\
\hline & $3+$ & 38 & 12,7 \\
\hline \multirow{2}{*}{ Evinde internet bulunma durumu } & Var & 268 & 89,3 \\
\hline & Yok & 32 & 10,7 \\
\hline \multirow{2}{*}{ Evinde bilgisayar bulunma durumu } & Var & 257 & 85,7 \\
\hline & Yok & 43 & 14,3 \\
\hline Toplam & & 300 & 100 \\
\hline
\end{tabular}


Tablo 2. Çalıșma grubunun oyun oynama faaliyetlerine ilișkin bilgiler

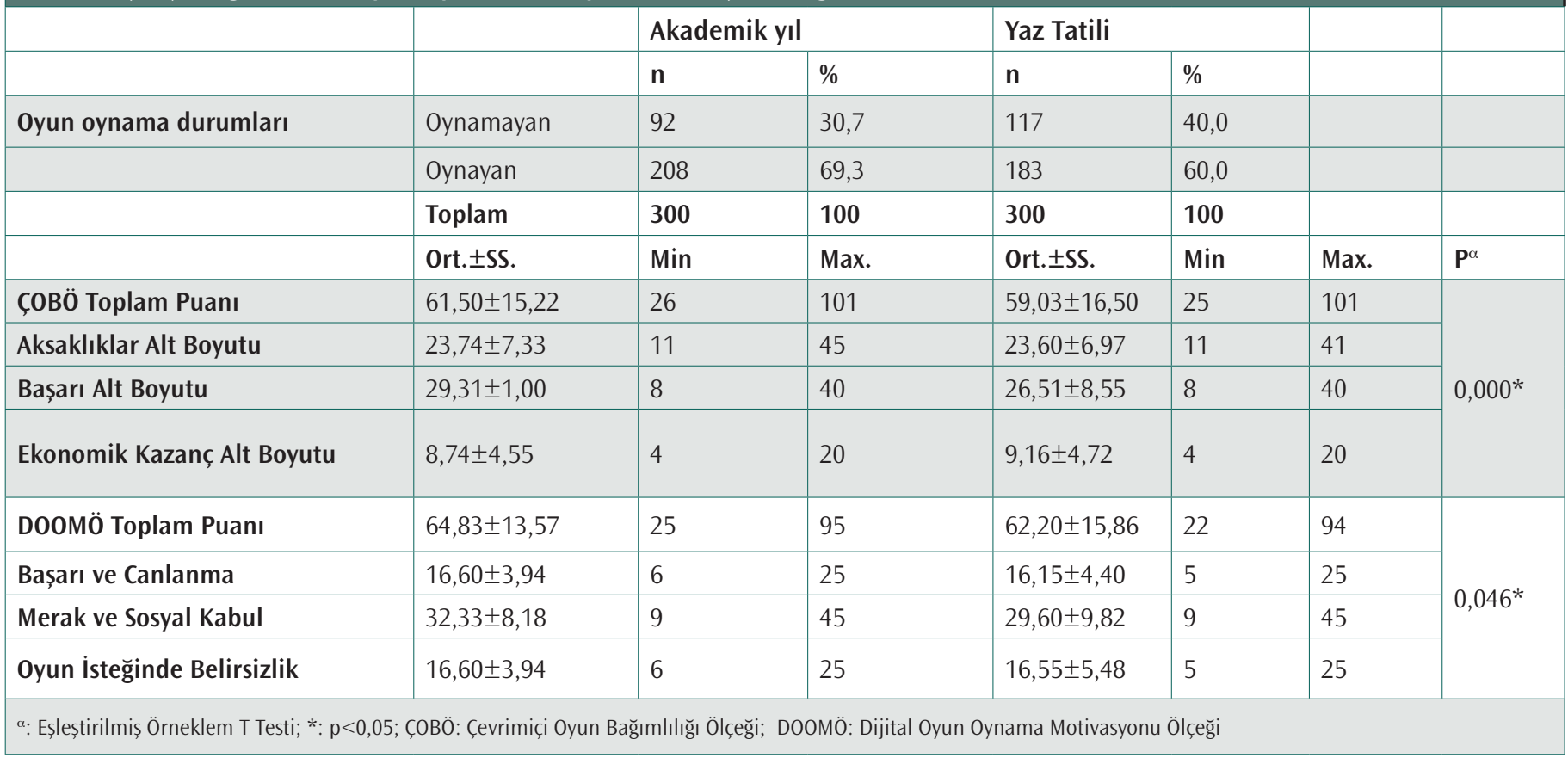

Akademik yı içerisinde 8-10, 6-8, 4-6 ve 2-4 saat oyun oynayanlar, 0-1 saat oynayanlara; 8-10 ve 6-8 saat oynayanlar 1-2 saat oynayanlara; 8-10 saat oynayanlar, 2-4 saat oynayanlara göre ÇOBÖ'den daha yüksek puan almışlardır. 8-10, 6-8, 4-6, 2-4 ve 1-2 saat oynayanlar, 0-1 saat oynayanlara; 8-10 saat oynayanlar, 1-2 saat ve 2-4 saat oynayanlara göre D00MÖ’den daha yüksek puan almışlardır.

Eğitim öğretim yılı içerisinde her gün oynayanlar, haftada 5-6, 3-4, 1-2 ve ayda birkaç kere oynayanlara göre çOBÖ'den daha yüksek puan almışlardır. Her gün oynayanlar, ayda 5-6 kere oynayanlara göre D00MÖ'den daha yüksek puan almışlardır.

Yaz tatilinde 6-8 ve 8-10 saat oyun oynayanlar, 0-1, 1-2 ve 2-4 saat oynayanlara göre ÇOBÖ'den daha yüksek puan almışlardır. 8-10 saat oyun oynayanlar, 0-1, 1-2 ve 2-4 saat oynayanlara göre D00MÖ'den daha yüksek puan almışlardır. Her gün oynayanlar, haftada 1-2, 3-4 ve ayda birkaç kere oynayanlara; haftada 3-4 gün oynayanlar, ayda birkaç kere oynayanlara göre hem çOBÖ hem de D00MÖ'den daha yüksek puan almışlardır.

Yaz tatilinde 2-4 ve 6+ saat video izleyenler, 0-1 saat izleyenlere göre, 1-2, 2-4 ve 6+ saat izleyenler hiç izlemeyenlere göre D00MÖ'den daha yüksek puan almıșlardır.

Eğitim öğretim yılı içerisinde öğrencilerin aile içi ilişkiler, arkadașlık ilișkileri, okul içi ilișkileri, ders bașarısındaki durumları ve video izleme saatleri arasında oyun bağımlılığı ve motivasyonunda anlamlı bir farklılık içermemektedir( $p>0,05)$.

Hem eğitim öğretim yılı hem de yaz tatilinde öğrencilerin oyun oynama motivasyonlarının oyun bağımlılı̆̆ını ne șekilde yordadığını ortaya koymak için basit doğrusal regresyon analizi yapılmıştır. Analiz sonucunda eğitim-öğretim yılı içinde oyun bağımlılığındaki değişimin \%39'unun, yaz tatilinde ise \%57'sinin oyun oynama motivasyonu ile açıklanabileceği görülmüștür.

\section{Tartıșma}

Akademik yıl içerisinde de yaz tatilinde de oyun oynamayan ve yayın izlemeyen öğrenciler arasında büyük oranda kız öğrenciler bulunmaktadır ve buna paralel olarak erkek öğrenciler kız öğrencilere göre oyunlara daha bağımlıdır. Genelde dünya üzerinde ve özelde Türkiye'de dijital oyuncularla yapılan birçok çalışmada oyuncuların çoğunun erkek olduğu (4); (27); (28), oyunların çoğunun erilliğe atfedilen araba, silah, şiddet gibi ögeleri içerdiği görülmektedir. Yani toplumsal cinsiyet eşitsizliğinin hayatın diğer alanlarında olduğu gibi oyunlar üzerinde de etkili olduğu ve çocukların küçük yaşlardan itibaren bu eylemleri, söylemleri benimseyerek büyüdükleri bir kültürün tekrarlanarak pekiștiği söylenebilir.

Hem akademik yıl içinde hem de yaz tatilinde daha uzun süre, sık aralıklarla oyun oynayan öğrencilerin daha kısa süre, daha az aralıklarla oynayanların daha seyrek oynayanlara göre oynama motivasyonları yüksektir ve oyun bağımlığına yatkındırlar. Literatürde oyun oynama süresi arttıkça oyun bağımlılığının arttığına ilișkin çalıșmalar mevcuttur $(11,16,29,30)$. Ancak oyun bağımlılığına etki eden faktörler ele alınırken oyun oynama süresi tek başına değerlendirilmemektedir. Oyuncu günün büyük bir kısmını oyun oynayarak geçirse bile, eğer oyun oynama davranışı, yașamında olumsuz sonuçlara yol açmıyorsa, bu davranışının bağımlılık olarak değerlendirilmeyeceği söylenebilmektedir (31). 
Tablo 3. Öğrencilerin sosyodemografik özellikleri ve oyun oynama faaliyetleri ile ÇOBÖ ve D00MÖ'den aldıkları puanlar arasındaki ilișkiler

\begin{tabular}{|c|c|c|c|c|c|c|c|c|c|c|}
\hline \multicolumn{6}{|l|}{ Akademik Yıl } & \multicolumn{5}{|c|}{ Yaz Tatili } \\
\hline \multirow[t]{2}{*}{ ÇOBÖ } & & & & D00MÖ & & ÇOBÖ & & & D00MÖ & \\
\hline & n (208) & Ort. \pm ss. & $\mathrm{p}$ & Ort. \pm ss. & $p$ & n (183) & Ort. \pm S.S. & $p$ & Ort. \pm ss. & $p$ \\
\hline \multicolumn{11}{|l|}{ Cinsiyet } \\
\hline Kadın & 83 & $54,50 \pm 13,90$ & \multirow{2}{*}{$0,000^{*}$} & $58,21 \pm 13,60$ & \multirow{2}{*}{$0,000^{*}$} & 65 & $51,10 \pm 13,95$ & \multirow{2}{*}{$0,000^{*}$} & $55,10 \pm 14,43$ & \multirow{2}{*}{$0,000^{*}$} \\
\hline Erkek & 125 & $66,14 \pm 14,30$ & & $69,23 \pm 11,68$ & & 118 & $63,40 \pm 16,21$ & & $66,11 \pm 15,30$ & \\
\hline \multicolumn{11}{|c|}{ Aile içi iliş̦iler } \\
\hline Kötü & 11 & $57,81 \pm 19,03$ & \multirow{3}{*}{0,071} & $64,09 \pm 20,63$ & \multirow{3}{*}{0,960} & 12 & $56,16 \pm 19,41$ & \multirow{3}{*}{0,396} & $63,41 \pm 19,91$ & \multirow{3}{*}{0,898} \\
\hline Orta & 42 & $66,16 \pm 16,13$ & & $64,47 \pm 14,00$ & & 38 & $62,10 \pm 18,03$ & & $65,97 \pm 17,40$ & \\
\hline İyi & 155 & $60,49 \pm 14,51$ & & $64,98 \pm 12,95$ & & 133 & $58,42 \pm 15,78$ & & $61,87 \pm 15,12$ & \\
\hline \multicolumn{11}{|c|}{ Arkadașlık ilișkileri } \\
\hline Kötü & 7 & $70,14 \pm 19,61$ & \multirow{3}{*}{0,234} & $65,14 \pm 19,61$ & \multirow{3}{*}{0,406} & 4 & $58,25 \pm 16,93$ & \multirow{3}{*}{0,194} & $50,25 \pm 23,69$ & \multirow{3}{*}{0,051} \\
\hline Orta & 35 & $62,97 \pm 12,29$ & & $67,62 \pm 11,30$ & & 37 & $63,43 \pm 14,60$ & & $67,22 \pm 13,73$ & \\
\hline İyi & 166 & $60,82 \pm 15,53$ & & $64,23 \pm 13,74$ & & 142 & $57,91 \pm 16,87$ & & $60,91 \pm 15,78$ & \\
\hline \multicolumn{11}{|c|}{ Okul İçi ilișkiler } \\
\hline Kötü & 10 & $68,30 \pm 13,71$ & \multirow{3}{*}{0,293} & $68,40 \pm 9,65$ & \multirow{3}{*}{0,542} & 10 & $61,20 \pm 17,17$ & & $63,50 \pm 16,68$ & \\
\hline Orta & 79 & $61,96 \pm 13,14$ & & $63,81 \pm 11,54$ & & 68 & $55,75 \pm 13,96$ & 0,116 & $59,69 \pm 14,69$ & 0,259 \\
\hline İyi & 119 & $60,62 \pm 1652$ & & $65,21 \pm 15,03$ & & 105 & $60,96 \pm 17,72$ & & $63,70 \pm 16,45$ & \\
\hline Ders bașarısı & & & & & & & & & & \\
\hline Kötü & 29 & $63,24 \pm 13,31$ & & $63,72 \pm 13,07$ & & 23 & $63,47 \pm 17,37$ & & $63,73 \pm 18,35$ & \\
\hline Orta & 121 & $62,75 \pm 15,18$ & 0,120 & $66,26 \pm 13,24$ & 0,185 & 110 & $58,21 \pm 17,13$ & 0,380 & $61,90 \pm 15,60$ & 0,881 \\
\hline İyi & 58 & $58,01 \pm 15,86$ & & $62,41 \pm 14,32$ & & 50 & $58,80 \pm 14,55$ & & $62,16 \pm 15,50$ & \\
\hline Oyuna harca & n saat & & & & & & & & & \\
\hline $0-1$ saat & 46 & $53,50 \pm 13,65$ & & $56,10 \pm 13,92$ & & 43 & $50,79 \pm 16,01$ & & $57,02 \pm 13,79$ & \\
\hline 1-2 saat & 73 & $59,61 \pm 14,74$ & & $65,00 \pm 12,40$ & & 33 & $55,39 \pm 14,15$ & & $59,63 \pm 15,15$ & \\
\hline 2-4 saat & 49 & $63,38 \pm 12,52$ & $0000 *$ & $66,69 \pm 11,48$ & $0000 *$ & 43 & $55,95 \pm 14,66$ & $0 \Omega 00 *$ & $59,37 \pm 16,34$ & $0000 *$ \\
\hline 4-6 saat & 26 & $67,34 \pm 13,23$ & 0,000 & $70,07 \pm 10,20$ & 0,000 & 18 & $61,33 \pm 12,53$ & 0,000 & $62,94 \pm 13,23$ & 0,000 \\
\hline 6-8 saat & 7 & $77,42 \pm 14,69$ & & $71,28 \pm 18,14$ & & 15 & $70,73 \pm 13,29$ & & $69,86 \pm 15,88$ & \\
\hline $8+$ saat & 7 & $82,85 \pm 15,67$ & & $81,57 \pm 11,41$ & & 31 & $71,64 \pm 15,67$ & & $71,90 \pm 15,52$ & \\
\hline Oyun oynam & iklığı & & & & & & & & & \\
\hline Her gün & 35 & $72,34 \pm 11,92$ & & $69,80 \pm 11,81$ & & 82 & $66,14 \pm 16,32$ & & $67,76 \pm 15,58$ & \\
\hline $\begin{array}{l}\text { Haftada 5-6 } \\
\text { kere }\end{array}$ & 33 & $60,93 \pm 11,55$ & & $62,78 \pm 11,91$ & & 33 & $58,60 \pm 14,12$ & & $60,36 \pm 15,91$ & \\
\hline $\begin{array}{l}\text { Haftada 3-4 } \\
\text { kere }\end{array}$ & 43 & $58,18 \pm 16,86$ & $0,000^{*}$ & $64,46 \pm 15,85$ & $0,043^{*}$ & 32 & $24,56 \pm 11,01$ & $0,000^{*}$ & $59,06 \pm 13,54$ & 0,000 * \\
\hline $\begin{array}{l}\text { Haftada 1-2 } \\
\text { kere }\end{array}$ & 63 & $61,15 \pm 15,45$ & & $65,88 \pm 14,52$ & & 10 & $48,80 \pm 14,88$ & & $51,70 \pm 17,35$ & \\
\hline $\begin{array}{l}\text { Ayda birkaç } \\
\text { kere }\end{array}$ & 34 & $55,70 \pm 13,87$ & & $60,23 \pm 10,20$ & & 26 & $46,61 \pm 15,48$ & & $54,88 \pm 12,93$ & \\
\hline Video izleme & urumu & & & & & & & & & \\
\hline Evet & 155 & $65,16 \pm 13,99$ & $0000 *$ & $68,41 \pm 11,71$ & $0000 *$ & 135 & $62,40 \pm 15,96$ & $0 \Omega \cap 0 *$ & $64,81 \pm 16,20$ & $0000 *$ \\
\hline Hayır & 53 & $50,77 \pm 13,61$ & 0,000 & $54,37 \pm 13,31$ & 0,000 & 48 & $49,58 \pm 14,28$ & 0,000 & $54,85 \pm 12,30$ & 0,000 \\
\hline Videoya harc & Ian saat & & & & & & & & & \\
\hline 0-1 saat & 64 & $60,15 \pm 14,27$ & & $61,90 \pm 14,16$ & & 47 & $56,85 \pm 15,11$ & & $60,91 \pm 14,28$ & \\
\hline 1-2 saat & 53 & $62,35 \pm 15,60$ & & $64,92 \pm 12,37$ & & 33 & $62,93 \pm 13,10$ & & $65,09 \pm 13,93$ & \\
\hline 2-4 saat & 24 & $58,50 \pm 14,35$ & 0344 & $68,79 \pm 13,16$ & 0230 & 31 & $68,09 \pm 18,65$ & $0,000 *$ & $68,41 \pm 18,93$ & $0.001 *$ \\
\hline 4-6 saat & 10 & $67,30 \pm 10,58$ & 0,344 & $70,00 \pm 13,02$ & 0,230 & 14 & $62,50 \pm 17,17$ & & $62,92 \pm 20,84$ & 0,001 \\
\hline $6+$ saat & 4 & $73,75 \pm 15,39$ & & $69,00 \pm 11,74$ & & 10 & $68,90 \pm 10,55$ & & $73,70 \pm 11,63$ & \\
\hline İzlemeyenler & 53 & $61,60 \pm 16,81$ & & $65,20 \pm 14,10$ & & 48 & $49,58 \pm 14,28$ & & $54,85 \pm 12,30$ & \\
\hline
\end{tabular}


Tablo 4. DOOMÖ ve ÇОВÖ arasında basit doğrusal regresyon

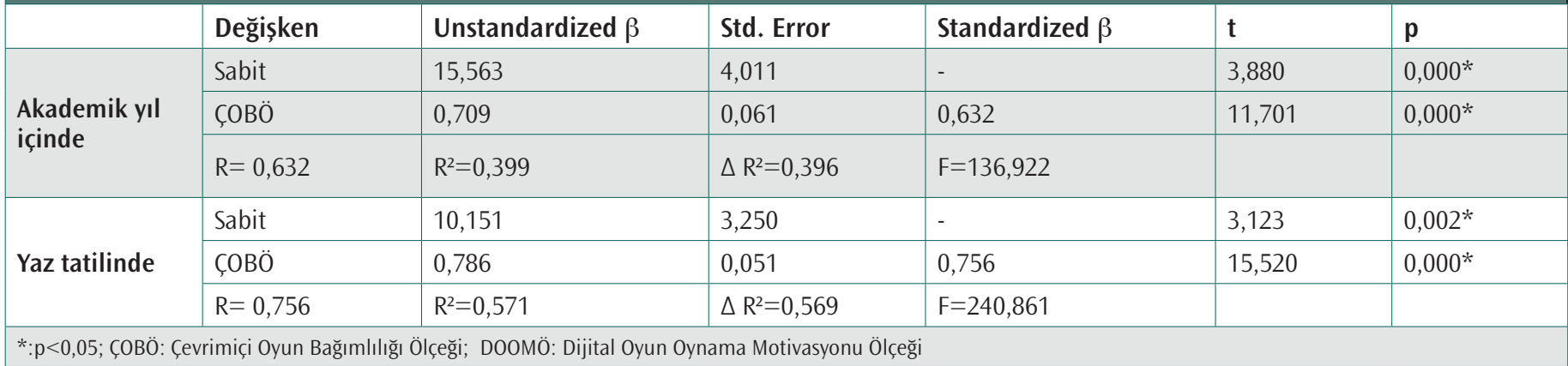

ÇOBÖ'den alınan puanlar incelendiğinde öğrencilerin yaz tatiline göre akademik yıl içerisinde, oyun oynama faaliyetleri sebebiyle daha çok aksaklıklar (uyku düzeninde bozulma, yemek yeme gibi temel ihtiyaçları erteleme, derse geç kalma vb.) yașadıkları, oyunlarda daha çok başarı hissettikleri görülmüștür. Bu bağlamda araștırmaya katılan öğrencilerin eğitim öğretim yılı içerisindeki oynama davranışlarının biyolojik, sosyal ve akademik yaşantılarına zarar vermesi sebebiyle problemli olduğu söylenebilir. Oyun oynamaya harcanan sürenin artması sonucunda gençlerin iyilik hallerinin zarar görebileceği ve oyun bağımlılı̆ının olușmasına yönelik bir risk faktörünün oluşabileceği söylenebilmektedir. Uzun süre oyun oynamanın kısa süre oyun oynamaya göre uyku süresini ve verimliliğini azalttı̆̆ı; oyuncunun ailesi ile sorunlar yaşamasına yol açı̆ğı, akademik başarının düșmesine sebep olduğu, biyolojik sağlık üzerine olumsuz etkiler bıraktığı diğer araștırmalar tarafından da bulgulanmıştır $(17,32)$.

Öğrenciler oyun oynama faaliyetleri aracılığıyla akademik yıla göre yaz tatilinde daha çok ekonomik kazanç sağlamıștır. Oyuncuların oyunlar üzerinden ekonomik kazanç elde etmesiyle dijital oyun oynamanın artık bir hobi olmaktan uzaklaşıp, bir meslek ve kariyer haline geldiğini ve oyuncunun oyun oynama motivasyonunu değiştirdiği bilinmektedir (33). Ancak yine de araștırmaya katılan öğrencilerin oyunlardan gelir elde etme durumları, alt boyut kapsamında incelendiğinde, öğrencilerin çoğunluğunun oyunlardan gelir elde etmediği görülmüștür. Bu durumun Türkiye'de insanlar tarafından oyun sektörünün henüz gerçek anlamda gelir getiren bir meslek olarak kabul edilmemesi, ailelerin çocuklarına oyun içi ekonomik faaliyetlerde bulunmaları konusunda temkinli davranmaları gerektiği üzerine ısrarlı düșünce ve tutumları ile açıklanabileceği düşünülmektedir.

Araștırma bulgularında beklenenin aksine, yaz tatiline göre akademik yıl içerisinde daha çok öğrencinin oyun oynadığı ve başkaları tarafından oynanan oyunların canlı yayınını veya kaydedilmiş videolarını izlediği görülmüştür. Bu durum öğrencilerin akademik yıl içerisindeki boş zaman değerlendirme, sıkıntıdan kurtulma isteklerinin giderilmesini sağlamada dijital oyunların en iyi alternatiflerden biri olarak görülmesinden kaynaklanması olarak yorumlanabilir.

Akademik yıl içerisindeki oyun oynama faaliyetlerinin, bağımlılık düzeylerinin ve motivasyonlarının yaz tatiline göre daha yüksek olması çeşitli etmenlerce açıklanabilir. Öğrencilerin yaz tatillerinde, eğitim öğretim yılına göre daha çok rekreatif faaliyetlerde bulunma fırsatına sahip olmaları, ailesine ekonomik katkı sağlamak amacıyla bir işe başlamaları dolayısıyla oyun oynamaya daha az vakit kalması gibi etmenler öğrencilerin oyun oynama faaliyetlerini şekillendirebilmektedir (34).

Araștırma yalnızca bir okulda gerçekleştirilmesi ve başlangıçta belirlenen 384 örneklem sayısına ulaşamaması sebebiyle kısıtıılığa sahiptir. Bu bakımdan gençlerin oyun oynama motivasyonlarını ve oyun oynama davranıșlarını inceleyecek daha büyük örneklemle gerçekleștirilecek çalıșmalara gereksinim duyulmaktadır.

Sonuç olarak öğrenciler okulların kapanmasıyla tatillerini ya da akademik yıl içerisinde okul dışı zamanlarını çeșitli şekillerde değerlendirmektedirler. Boș zamanlarını kendi iyilik hallerine olumlu katkıda bulunarak geçiren öğrencilerin bulunmasının yanı sıra kimi öğrenciler uzun saatlerce bilgisayar oynayarak biyo-psiko-sosyal sağlıklarına zarar verici davranıșlarda bulunabilmektedirler. Araştırmanın konusu ile ilgili olarak uzun saatler boyunca bilgisayar oynayan çocuklarda sosyalleșmenin azalmasıyla, oyun içi davranış kalıplarının, ifade biçimlerinin öğrenilmesiyle birlikte ergenlik döneminde olan öğrencilerde aile, arkadaș ilișkilerinde sorunların ortaya çıkması kaçınılmaz olabilmektedir. Dijital oyunların fazla kullanımı bireyi sosyal, biyolojik ve psikolojik yönlerden etkilemektedir ancak odaklanılması gereken önemli bir diğer noktanın ergenin oyunları algılama biçimi ve ergeni uzun süre oyuna sürükleyen nedenlerin keșfedilmesi olduğu düşünülmektedir. Bu bağlamda oyun oynama motivasyonlarının farklı değișkenlerle ele alınması önemlidir. Çalıșma alanlarından biri olan çocuk ve gençlerin iyilik halinin artırılması noktasında sosyal hizmet disiplininin ergenlerle dijital bağımlılıklar konusunda çalışması, ergenlerin problemli teknoloji kullanımlarının kökenlerinin anlaşılmasına, 
problemli kullanımların sağlıklı davranıșlara dönüștürülmesine yardımcı olacaktır. Ergenlerin kurmuş oldukları oyun oynama, aile, arkadaș șemalarının öğrenilmesi ve olumsuz șemaların daha sağlıklı olanlarla değiştirilmesi sosyal hizmet uygulamalarından yalnızca birkaçıdır. Problemli oyun oynama davranıșının altında yatan olumsuz șemaların keșfedilmesi ve ișlevsel șemaların kazandırılması, teknoloji çağında büyümekte olan çocuk ve gençlerin problemli teknoloji kullanım davranışlarının önüne geçecektir. Özellikle okullarda öğrencilerin yaşam becerilerinin geliștirilmesi ve bu becerilerin sürdürülmesi üzerine çalıșmaların yapılması öğrencilerin benlik saygılarını geliștirmelerine, sorunlarla baş edebilmelerine yardımcı olarak, çocuk ve gençlerin dijital bağımlılıklara karşı koruyucu birer davranış kazanmalarını sağlayacaktır. Bu bakımdan okul ortamlarında sosyal hizmet uzmanlarının gerçekleștireceği çalıșmalara ihtiyaç duyulmaktadır.

\section{Kaynaklar}

1. Ayan S, Memiş U. Erken çocukluk döneminde oyun. Selçuk Üniversitesi Beden Eğitimi ve Spor Bilim Dergisi 2012; 14(2): 143-149.

2. Hazar Z, Tekkurșun Demir G, Dalkıran H. Ortaokul öğrencilerinin geleneksel oyun ve dijital oyun algılarının incelenmesi karşılaştırmalı metafor çalışması. Spormetre, 2017; 15(4): 179-190.

3. Yiğit Açıkgöz F, Yalman A. Dijital oyunların çocukların kișilik ve davranışları üzerinde etkisi: GTA 5 oyunu örneği. Akdeniz Üniversitesi Illetişim Fakültesi Dergisi, (AKIL). 2018; 29 (Özel sayı): 163-180.

4. Kaya AB. Çevrimiçi oyun bağımlıı̆̆ı ölçeğinin geliștirilmesi: geçerlik ve güvenirlik çalışması. Yüksek Lisans Tezi, Tokat: Gaziosmanpaşa Üniversitesi, 2013.

5. Binark M, Bayraktutan Sütcü G. Kültür Endüstrisi Ürünü Olarak Dijital Oyun. istanbul: Kalkedon Yayınları, 2008.

6. Aydemir 0. Türkiye Oyun Sektörü Raporu, 2020. İstanbul: Gaming in Turkey, 2020.

7. Solmaz A, Okumuş M, Okumuş K. Dijital oyunlarda müstehcenlik. Uluslararası Oyun ve Oyuncak Kongresi, 2015. Erzurum.

8. Zastrow C, Krist-Ashman KK. İnsan DAVRANIŞI VE SOSYAL ÇEVRE 1. Ankara: Nika Yayınevi, 2014.

9. Griffiths MD. The role of context in online gaming excess and addiction: some case study evidence. Int J Ment Health and Addict. 2010; 8(1): 119-125.

10. Triberti S, Milani L, Villani D, et al. What matters is when you play: Investigating the relationship between online video games addiction and time spent playing over specific day phases. Addict Behav Rep. 2018; 8: 185188.

11. Gürgan U, Karaman, B, Minaz B. 14-24 Yaş arası öğrencilerde sosyal ve duygusal yalnızlığın oyun bağımlılı̆ı ile ilișkisi. Uluslararası Necatibey Eğitim ve Sosyal Bilimler Araștırmaları Kongresi (UNESAK 2018). 2018; 303356, Balıkesir.

12. Eryılmaz A, Deniz ME. Tüm Yönleriyle Bağımlılık. Ankara: Pegem Akademi, 2019.

13. Güzel M. Küreselleșme, internet ve gençlik kültürü. Küresel Illetişim Dergisi. 2006; 1: 1-16.
14. Hazar Z, Hazar M. Çocuklar için Dijital Oyun Bağımlılığı Ölçeği. International Journal of Human Sciences. 2017; 14(1): 203-216.

15. Muslu GK, Bolışık B. Çocuk ve gençlerde internet kullanımı. TSK Koruyucu Hekimlik Bülteni. 2009; 8(5): 445-450.

16. Kim K, Kim K. Internet game addiction, parental attachment and parenting of adolescents in South Korea. J Child Adolesc Subst Abuse 2015; 24(6): 366371.

17. King DL, Gradisar M, Drummond A, et al. The impact of prolonged violent video-gaming on adolescent sleep: an experimental study. J Sleep Res. 2012; 22(2): 137-143.

18. Davis RA. A cognitive-behavioral model of pathological internet use. Comput Hum Behav. 2001; 17(2): 187-195.

19. Lee DM, Jeonga EJ, Kimb DJ. Why do some people become addicted to digital games more easily? A study of digital game addiction from a psychosocial health perspective. Int J Hum Comput Interact 2017; 33(3): 199-214.

20. American Psychiatric Association. Diagnostic and Statistical Manual of Mental Disorders (DSM-5). Arlington, American Psychiatric Association, 2013.

21. Gentile DA, Choo H, Liau A, et al. Pathological video game use among youths: a two-year longitudinal study. Pediatrics 2011; 127(2): e319-e329.

22. Leung, L. Stressful life events, motives for internet use and social support among digital kids. Cyberpsychol Behav 2007; 10(2): 204-214.

23. Yalçın Irmak A, Erdoğan S. Predictors for digital game addiction among turkish adolescents. J Addict Nurs. 2019; 30(1): 49-56.

24. Yılmaz B, Bekiroğlu S. Çocukluk döneminde dijital bağımlılık, Paslı F, Aslantürk H (editörler). 1. Baskı, Ankara: Nobel Akademik Yayıncılık. 2020; 357-374.

25. Gürbüz S, Şahin F. Sosyal Bilimlerde Araștırma Yöntemleri. Ankara: Seçkin Yayıncılık, 2014

26. Tekkurşun Demir G, Hazar Z. Dijital oyun oynama motivasyonu ölçeğ (DOOMÖ): geçerlik ve güvenirlik çalıșması. Niğde Üniversitesi Beden Eğitimi Ve Spor Bilimleri Dergisi. 2018; 12(2): 128-138.

27. Akın A, Turan ME, Akın Ü. Problemli çevrimiçi oyun kullanımı ölçeği türkçe formu: geçerlik ve güvenirlik çalışması. Birey ve Toplum. 2015; 5(10): 65-77.

28. Çavuș, S, Ayhan B, Tuncer M. Bilgisayar oyunları ve bağımlılık: üniversite öğrencileri üzerine bir alan araştırması. İletişim Kuram ve Araştırma Dergisi. 2016; 43: 265-289.

29. Longman H, O'Connor E, Obst P. The effect of social support derived form world of Warcraft on negative psychological symptoms. Cyberpsychol Behav 2003; 12(5): 563-566.

30. Irwansyah MA. Internet uses, gratificaitons, addiction and loneliness among international students. PHD thesis, Hawaii: University of Hawaii, Department of Communication, 2005.

31. Weinstein AM. Computer and video game addiction-A comparison between game users and non-game users. Am J Drug Alcohol Abuse 2010; 36(5): 268-276.

32. Civan Kemiksiz, R. Çevrimiçi bağımlıı̆̆ın habitatı: çevrimiçi oyuncuların e-spor faaliyetleri ve oyun bağımlılığı ilișkisi. Yüksek lisans tezi, İstanbul: İstanbul Üniversitesi Sosyal Bilimler Enstitüsü, 2019.

33. Griffiths MD. The psychosocial impact of professional gambling, professional video gaming \& eSports. Casino Gaming International 2017; 28: 59-63.

34. Sezer Ö, Sumbas E. Lise öğrencilerinin yaz tatillerini kullanım biçimlerinin bazı değișkenler açııında incelenmesi. İnönü Üniversitesi Uluslararası Sosyal Bilimler Dergisi. 2018; 7(1): 173-189. 